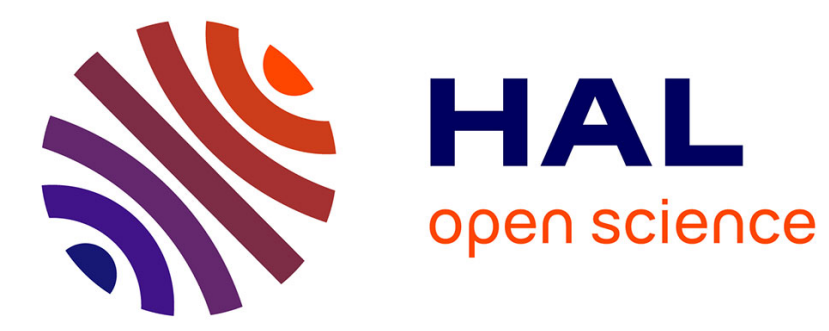

\title{
The acquisition of tense-aspect in child second language English
}

Belma Haznedar

\section{To cite this version:}

Belma Haznedar. The acquisition of tense-aspect in child second language English. Second Language Research, 2007, 23 (4), pp.383-417. 10.1177/0267658307080330 . hal-00570733

\section{HAL Id: hal-00570733 \\ https://hal.science/hal-00570733}

Submitted on 1 Mar 2011

HAL is a multi-disciplinary open access archive for the deposit and dissemination of scientific research documents, whether they are published or not. The documents may come from teaching and research institutions in France or abroad, or from public or private research centers.
L'archive ouverte pluridisciplinaire HAL, est destinée au dépôt et à la diffusion de documents scientifiques de niveau recherche, publiés ou non, émanant des établissements d'enseignement et de recherche français ou étrangers, des laboratoires publics ou privés. 


\section{The acquisition of tense-aspect in child second language English}

\section{Belma Haznedar Boğaziçi University}

Received March 2006; revised September 2006; accepted October 2006

The aim of this article is two-fold: to test the Aspect Hypothesis, according to which the early use of tense-aspect morphology patterns by semantic/aspectual features of verbs, and Tense is initially defective (e.g. Antinucci and Miller, 1976; Bloom et al., 1980; Andersen and Shirai, 1994; 1996; Robison, 1995; Shirai and Andersen, 1995; Bardovi-Harlig, 1998; Shirai, 1998); and to test Gavruseva's aspectual features account, according to which inherent aspectual properties of the verbs such as telicity and punctuality determine which verbs will be non-finite and which verbs will not (Gavruseva, 2002; 2003; 2004) in child L2 acquisition. Based on longitudinal data from a Turkish child second language (L2) learner of English, we present counter evidence for both hypotheses. First, it is shown that despite the fact that the early production of past tense morphology occurs exclusively with punctual predicates, data from copula $b e$, auxiliary $d o$ and pronominal subjects do not show any evidence for defective tense. Second, contrary to what is predicted in Gavruseva's hypothesis, the rate of uninflected punctual verbs is much higher than that of uninflected non-punctual verbs in the child L2 grammar.

Keywords: child L2 acquisition, L2 tense-aspect morphology, Underspecification of Aspect Hypothesis, optional/root infinitives in L2 


\section{Introduction}

It has long been noted that grammatical morphemes cause problems for learners both in first (L1) and second language (L2) acquisition (e.g. Brown, 1973; Dulay et al., 1982). In most cases, learners exhibit optionality or variability in the use of morphology relating to tense, agreement, case and/or gender as well as functional elements such as determiners, complementizers and auxiliaries. To this end, much work in L1 and L2 acquisition since the 1970s has explored the presence or absence of verbal and nominal inflection. In regard to the verbal domain, the focus has been on the development of tense-aspect morphology in monolingual and bilingual language acquisition (e.g. Antinucci and Miller, 1976; Bloom et al., 1980; Schlyter, 1990; Shirai and Andersen, 1995; Shirai, 1998; Behrens, 2001), as well as in adult L2 acquisition (e.g. Robison, 1995; BardoviHarlig and Bergström, 1996; Slabakova, 1999; 2001). Following the Aspect Hypothesis, in some of these studies L1 and L2 researchers have argued that verbal inflections in early interlanguage grammars function primarily as markers of lexical aspect. That is, when inflections emerge, they are not evenly distributed across all verbs, but mark inherent aspect, not deictic tense.

In child L 2 acquisition, on the other hand, recent work has mainly concentrated on the acquisition of tense and agreement morphology (e.g. Lakshmanan, 1994; Gavruseva and Lardiere, 1996; Grondin and White, 1996; Prévost, 1997; Paradis et al., 1998; Haznedar, 2001; Ionin and Wexler, 2002). With the exception of some studies (e.g. Rohde, 1996; Gavruseva, 2002; 2003; 2004), there has been little discussion of how tense-aspect morphology develops in child L2 acquisition. Based on longitudinal data from a Turkish-speaking child L2 learner of English, the primary aim of this article is to investigate the acquisition of tense-aspect in child L2 acquisition of English, with special reference to the Aspect Hypothesis and a recent, alternative account proposed by Gavruseva (2002; 2003; 2004): the Underspecification of AspP Hypothesis.

The organization of the article is as follows. Section II presents a brief overview of the difference between grammatical aspect and lexical aspect. Section III reviews theories on the acquisition of tense-aspect morphology in L1 and L2 acquisition. Section IV introduces Gavruseva's account of root infinitives in child L2 acquisition, with an emphasis on verb semantics and the notion of the underspecification of the AspP. 
Section V presents the child L2 data and its analysis. Finally, Section VI discusses the findings in terms of the main tenets of the Aspect Hypothesis and the Underspecification of AspP Hypothesis, with an emphasis on the development of tense marking, copula be, auxiliary $d o$, pronominal subjects as well as the distribution of punctual vs. nonpunctual verbs in the child L2 data analysed in this study. The Aspect Hypothesis holds that in early stages of language acquisition only inherent aspectual distinctions are encoded by verbal morphology, not tense or grammatical aspect. As this study specifically deals with the acquisition of tense-aspect morphology, it is important to understand the distinction between grammatical aspect and lexical aspect. Therefore, the next section presents a brief overview of the difference between grammatical and lexical aspect.

\section{Grammatical aspect vs. lexical aspect}

Grammatical aspect, also known as viewpoint aspect, refers to aspectual distinctions that are encoded in a given language through auxiliaries and/or inflectional morphology (Smith, 1983; 1997). The progressive aspect in English and the perfective/imperfective aspect in Spanish type languages, for instance, are cases of grammatical aspect. Lexical aspect also known as situational aspect, inherent aspect or Aktionsart - on the other hand, is an inherent part of a lexical item or construction that expresses a situation or action (Comrie, 1976). In other words, it indicates a type of eventuality such as state, process or event (Bach, 1986; de Swart, 1998). For example, the verb know is inherently stative (i.e. continuous), while fall is inherently punctual (momentary and instantaneous). Vendler (1967) divided lexical aspect into four categories, as shown in (1).

$\begin{array}{llll}\text { 1) State } & \text { Activity } & \text { Accomplishment } & \text { Achievement } \\ \text { want } & \text { run } & \text { make a cake } & \text { find } \\ \text { like } & \text { walk } & \text { write a novel } & \text { lose }\end{array}$

Types of eventualities correspond to aspectual classes that are defined in terms of semantic/aspectual features. Table 1 presents Vendler's four classes by means of binary semantic features. Each of the verb classes in Table 1 is characterized by a combination of the three features punctuality, 
Table 1 Semantic features of aspectual classes

\begin{tabular}{llll}
\hline & Punctual & Telic & Dynamic \\
\hline State & - & - & - \\
Activity & - & - & + \\
Accomplishment & - & + & + \\
Achievement & + & + & + \\
\hline
\end{tabular}

telicity and dynamicity. While punctual verbs are inherently telic (V[+telic], i.e. [+punctual] and [+dynamic]), an aspectual class of Statives is defined by an inherently atelic feature (V[-telic]; Vendler, 1967). Statives are static: without any additional energy they do not change. The other three categories, on the other hand, are dynamic. Activities are dynamic and atelic, accomplishments are dynamic, telic and durative, and achievements are dynamic, telic and punctual (Dowty, 1979; Smith, 1991). Under Vendler's formulation, Achievements are punctual in that, once they have taken place, they are over, e.g. finding a key; and accomplishments begin and continue an activity and bring it to an end point, as in baking a cake. ${ }^{1}$

We now turn to the acquisition of tense-aspect morphology in first and second language acquisition research.

\section{The acquisition of tense-aspect morphology in L1 and L2 acquisition}

The acquisition of tense-aspect morphology has been extensively investigated both in L1 and L2 acquisition research. In this section we briefly review early work in this area to prepare the discussion of theoretical issues to be investigated in the article.

\footnotetext{
${ }^{1}$ It should be noted that while Vendler's classification has generally been the most widely known analysis in the literature, it has been reinterpreted in subsequent research on lexical aspect. For instance, Smith (1997) modified Vendler's analysis and added 'semelfactive' verbs such as cough and knock that refer to a repeated event in English. She argued that while semelfactive verbs are similar to achievements in terms of punctuality, they differ from achievements as they do not refer to an endpoint. Other researchers also modified Vendler's classification in other ways. Instead of dividing verbs into four categories, some researchers used pairs of contrasts in their analysis, such as stative vs. dynamic verbs, telic vs. atelic verbs and punctual vs. durative verbs. In analysis of creole languages, Bickerton (1975) specifically used semantic features such as punctual, durative and stative (for further discussion, see Comrie, 1976).
} 


\section{First language acquisition of aspect: the defective tense hypothesis}

One of the earliest studies of the acquisition of tense and aspect morphology is Brown's classic work on child L1 English (Brown, 1973). Brown found that the progressive aspect marker -ing, the first morpheme that emerged in the speech of English-speaking children, was never overgeneralized to stative verbs. He also noted that children used past tense morphology with a small group of punctual verbs such as fell, broke, dropped (Brown, 1973: 334).

In another longitudinal study, Bloom et al. (1980) worked with 1; 10-2;4-year-old English-speaking children. Similar to the Brown study, they found that the emergence of verbal morphology correlated with the lexical aspect of verbs. That is, -ing occurred almost always with action verbs such as play and run, -ed and irregular past forms occurred consistently with completive verbs such as find and fall, suggesting links between tense-aspect marking and inherent temporal features (i.e. lexical aspect).

In an experimental study with 3-8-year-old French-speaking children, Bronckart and Sinclair (1973) demonstrated that French-speaking children tend to use passé composé (perfective past tense) forms for actions with clear end results, and présent (present) tense forms for actions. They concluded that the distinction between result and process is perhaps the only aspectual feature in the speech of French-speaking children in the study.

In a similar vein, Antinucci and Miller (1976) examined naturalistic data from Italian-speaking children aged 1;6-2;6 and demonstrated that the children's early use of the perfective past tense form passato prossimo was restricted to Achievement verbs such as fall and break. Interestingly, they did not use activity and state verbs with passato prossimo but rather with imperfetto (imperfective past).

Aksu (1978, Aksu-Koç 1988) studied the development of tense, aspect and modality in the L1 acquisition of Turkish and reported similar findings to those discussed above. She found that the past form $-d I$ was first used with change of state verbs that specify an action with a clear result, whereas the reported past form $-m I_{\text {ş }}$ was used with verbs that indicate accomplished states. The progressive form -Iyor, on the other hand, was used exclusively with activity verbs. On the basis of these results, Aksu (1978) argued that aspectual features are acquired prior to temporal distinctions. In more recent work Aksu-Koç (1998) 
re-examines the relationship between tense-aspect morphology and lexical aspect in L1 Turkish, focusing on State, Activity, Accomplishment and Achievement verbs. Consistent with her earlier findings, she finds a strong relation between $-d I$ and punctual verbs and between -Iyor and activity verbs.

In sum, the studies reviewed in this section suggest that the early use of tense-aspect markers is restricted to lexical aspectual values of verbs. This acquisition pattern led to the development of various theoretical models of early morphological acquisition, one of which, the Aspect Hypothesis, ${ }^{2}$ has received considerable attention within the last three decades in both L1 and L2 acquisition research. ${ }^{3}$ The next section focuses on the Aspect Hypothesis in research into second language acquisition.

\section{Second language acquisition of aspect}

Early L2 research on the acquisition of aspect in the 1980s and 1990s also reported associations between lexical aspect and tense-aspect morphology, similar to those discussed in L1 acquisition research in the previous section. On the basis of data from the L2 acquisition of Spanish by English-speaking learners, Andersen (1991) found that past perfective (preterite) appeared earlier than past imperfective. While the order of acquisition with past perfective was Achievement, Accomplishment, Activity and States, the order of acquisition with past imperfective was State, Activity, Accomplishment and Achievements. With regard to semantic features of verbs, perfective past is first correlated with + punctual, + telic, + dynamic, whereas imperfective past with - punctual, - telic, - dynamic.

Studies of the L2 acquisition of English also reported similar associations between lexical aspect and tense-aspect morphology in both case studies and cross-sectional studies. Bardovi-Harlig and Reynolds (1995) tested classroom L2 learners using a cloze-type fill in the blanks test and showed that L2 learners found it more difficult to use past tense for Activities and States than for Achievements. Overall, Andersen (1991),

\footnotetext{
${ }^{2}$ This hypothesis is also known as The Aspect-before-Tense Hypothesis or The Primacy of Aspect Hypothesis.

${ }^{3}$ The other two well-known theoretical proposals are Bickerton's Language Bioprogram Hypothesis (Bickerton, 1984) and Slobin's Basic Child Grammar Hypothesis (Slobin, 1985), which are beyond the scope of this article.
} 
Robison (1990; 1995), Andersen and Shirai (1994; 1996), Bardovi-Harlig (1998) have all argued that the acquisition of verbal morphology is guided by the aspectual properties of verbs during the early stages of language acquisition. ${ }^{4}$ What this suggests is that the inherent aspectual properties of a verb play a role in its acquisition and learners acquire aspectual distinctions prior to tense features. This view is known as the Primacy of Aspect Hypothesis, according to which learners initially use tense markers to encode aspect. Following Vendler's (1967) verb classification (which is also adopted in the study reported here), the Primacy of Aspect Hypothesis predicts the following stages in the acquisition of verbal morphology (e.g. Andersen and Shirai, 1994; 1996; Bardovi-Harlig, 1995; Robison, 1995):

1) Learners first use past marking (e.g. English) on Achievement and Accomplishment verbs, and later extend it to Activity and Stative verbs.

2) In languages that encode the perfective/imperfective distinction, imperfective past appears later than perfective past, and imperfective past marking begins with stative verbs, extending next to Activity verbs, then to Accomplishment verbs, and finally to Achievement verbs.

3) In languages that have progressive aspect, progressive marking begins with Activity verbs, then extends to Accomplishment and Achievement verbs.

4) Progressive marking is not used incorrectly with Stative verbs. (Andersen and Shirai, 1996:533).

After this brief review of the Aspect Hypothesis in L2 acquisition research, we now turn to a recent model proposed by Gavruseva (2002; 2003; 2004) in order to account for Optional Infinitives/Root Infinitives in child L2 acquisition.

\section{An aspectual account of root infinitives in child L2 acquisition}

In recent work, Gavruseva $(2002 ; 2003 ; 2004)$ proposes an analysis of the infinitive-like verb forms in finite contexts, a phenomenon known as

\footnotetext{
${ }^{4}$ As pointed out by an anonymous reviewer, while the studies reviewed in this section offer clear evidence of aspect effects, they focus on adult L2 speakers in instructed situations, and not on child L2ers. Moreover, the nature of the data used in these studies differs from that of the child L1 studies reported in the previous section in terms of naturalness and spontaneity. The L1 studies used spontaneous oral production data, while the studies reviewed here used controlled tasks, e.g. elicited written data (Andersen, 1991), cloze test (Bardovi-Harlig and Reynolds, 1995).
} 
the Optional Infinitive stage or Root infinitive stage (henceforth, OI/RI), during which children acquiring Dutch, German, Swedish, French and English use infinitives in root contexts (e.g. Rizzi, 1994; Wexler, 1994). Leaving aside various proposals for OIs/RIs in L1 acquisition research, ${ }^{5}$ for the purposes of this article, we briefly review three major hypotheses identified in recent L2 literature with regard to infinitive-like verb forms. One is Rizzi's Truncation Model (Rizzi, 1994), the other one is the Missing Surface Inflection Hypothesis (Haznedar and Schwartz, 1997; Lardiere, 1998; 2000; Prévost and White 2000; White, 2003) and, finally, the third one is Gavruseva's Underspecification of AspP Hypothesis (Gavruseva, 2002; 2003; 2004).

According to Rizzi's Truncation Model, properties of RIs can be attributed to the optional truncation of projections in the clause structure. Under this account, while the adult grammar requires the projection of the full $\mathrm{CP}$, children have the possibility of not projecting the full $\mathrm{CP}$ and truncate it at any syntactic node below CP. Thus, if truncation applies below $\mathrm{TP}$, for example, no CP, AgrP or TP is projected. If CP is projected, AgrP and TP will be too. Variability, therefore, is the consequence of the projection of different roots. In contrast to the Truncation Model, the Missing Surface Inflection Hypothesis proposes that uninflected predicates result from mapping problems at the syntax-morphology interface. On this account, then, problems with the realization of morphology are attributed to failure to consistently access certain morphological forms from the lexicon (e.g. Haznedar and Schwartz, 1997; Lardiere, 1998; 2000; Prévost and White, 2000; Haznedar, 2001). Hence, the optional use of morphological forms does not indicate an impairment in the representation of the associated functional projections.

Gavruseva's approach $(2002 ; 2003 ; 2004)$, on the other hand, attempts to derive root infinitives from the aspectual properties of the verb. Based on Hoekstra and Hyams' (1998) earlier work on child L1 acquisition, which shows that optional/root infinitives in languages such as Dutch,

\footnotetext{
5 The phenomenon of root infinitives in child language has received a lot of attention in the last decade and presenting a detailed discussion of root infinitives is beyond the scope of this article. Therefore, the reader is referred to Wexler (1994), Rizzi (1994), Hoekstra and Hyams (1995; 1996; 1998) and Hoekstra et al. (1996) for various proposals ranging from the underspecification of the functional head Number (Hoekstra and Hyams, 1995) and Tense (Wexler, 1994; Bromberg and Wexler, 1995) to the truncation of syntactic representation (Rizzi, 1994).
} 
German and French occur with eventive predicates, ${ }^{6}$ Gavruseva (2002; $2003 ; 2004)$ relates the OI/RI phenomenon to the aspectual properties of the verb. Her model is based on a simplification of Vendler's (1967) aspectual system and uses only two aspectual features (punctuality and telicity) to distinguish the aspectual classes. The telicity feature is the basis for telic/atelic aspectual interpretations that can be drawn both at the level of Aktionsart (a verb stem level) and at the syntactic (VP/AspP) levels. Aktionsart-based telicity is taken as a semantic feature that defines the class of States (inherently atelic verbs) and Achievements (inherently telic verbs). Under Gavruseva's formulation, which is also used in the present study, eventives are divided into two categories of punctual vs. non-punctual eventives. Punctual eventives correspond to Vendler's Achievements, whereas non-punctual eventives include Vendler's Activities and Accomplishments.

Assuming a typology of verb classes based on the semantic features of telicity and punctuality, Gavruseva proposes that Stative verbs such as like and love are inherently atelic, as they are assumed to have no end point, and that punctual verbs such as break and fall are inherently telic, as they have an intrinsic end point. The telicity of non-punctual verbs such as eat, on the other hand, is dependent on the other elements in the VP. As proposed by Verkuyl $(1972 ; 1989)$, aspect is a compositional property of sentences and verb phrases in that nominal arguments contribute to aspectual interpretation. It is not a property of verb meaning only. Consider the examples in (2).

\footnotetext{
${ }^{6}$ Hoekstra and Hyams (1998) refer to this phenomenon as the eventivity constraint, according to which during the optional infinitive stage only eventive verbs appear in root contexts, while stative verbs in the same period are finite. Ferdinand (1996), for instance, shows that during the optional infinitive stage in early French, stative verbs are exclusively finite, whereas eventive verbs occur both in finite and non-finite forms. Wijnen (1996) also observes that 95\% (1790/1883) of root infinitives in the Dutch corpora from four children occur with eventive verbs, with the remaining 5\% (93/1883) with stative verbs. It should be noted that for Hoekstra and Hyams (1998), the eventivity constraint also accounts for the lack of auxiliary verbs in non-finite contexts (for early Dutch and Sano, see de Haan, 1986; for English, see Sano and Hyams, 1994). Sano and Hyams, for example, show that auxiliaries do not occur in root contexts. Assuming that inflected forms entail that I (AGR) features are specified, Sano and Hyams (1994) predict that null subjects should not appear with the inflected forms of the copula verb be. Data from Adam and Eve (Brown, 1973) and Nina (Suppes, 1973) indicate that in most cases children do not use null subjects with am/is/are. While null subjects occur with main verbs, the proportion of null subjects in sentences with the copula be is in fact very low: $0 \%$ in Eve's speech, $11.4 \%$ in Adam's speech and $4 \%$ in Nina's speech.
} 
392 The acquisition of tense-aspect in child L2 English

2) a. John ate a banana.

b. John ate the banana.

c. John ate bananas.

While the sentences (2a and b) are telic (terminative), (2c) is atelic. Clearly, since the verb form ate is the same, the aspectual difference between the sentences is associated with a difference between the nominals a banana, the banana and the bare plural bananas.

Gavruseva's proposal of aspectual types is schematized in (3).

3) Statives:

$\mathrm{V}[-$ telic $]$

Punctual eventives:

$\mathrm{V}[+$ telic $]$

Non-punctual eventives:

$\mathrm{V}[+/-$ telic $]$

Following Travis (1991) and Borer (1994), Gavruseva (2002) assumes that telicity is a syntactic feature that is checked by the verb in an AspP, as in (4).

4)
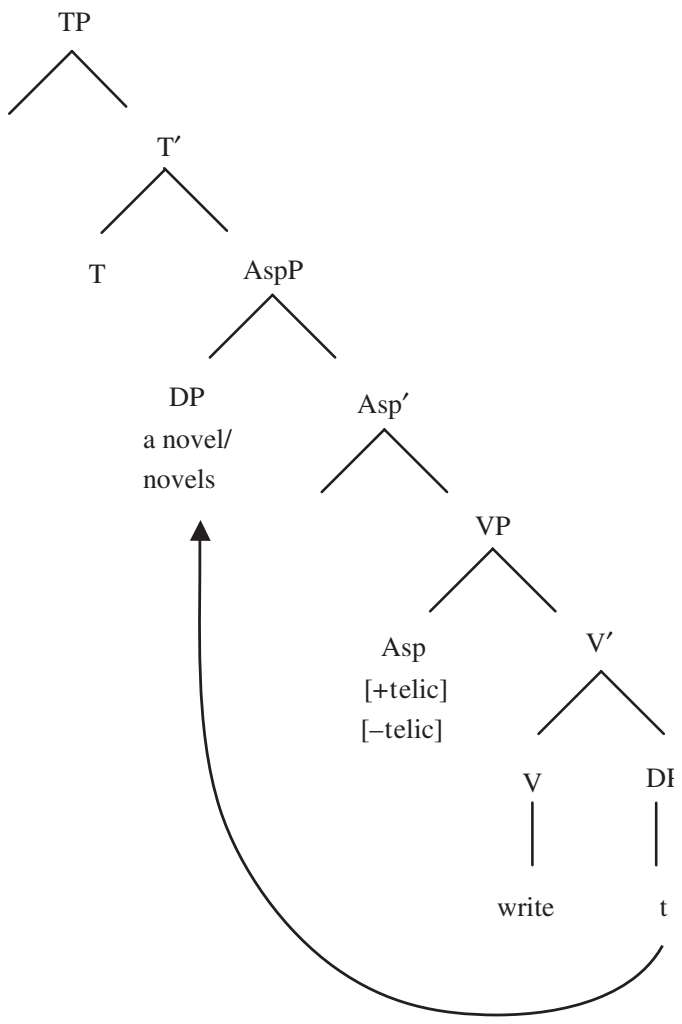
On her account, only the non-punctual eventives, which are unspecified for telicity, must move through an AspP projection. Their telicity feature is then determined by the argument in the specifier of AspP. In the tree in (4), the complement a novel would check a [+telic] feature while novels would check a [-telic] feature. In line with Guéron and Hoekstra (1995) and Hoekstra and Hyams (1998), ${ }^{7}$ Gavruseva also assumes that the temporal interpretation of the clause is given by a tense chain where AspP is included, as shown in (5):

5) $\mathrm{TO}_{\mathrm{i}} \mathrm{F}_{1} \ldots \mathrm{F}_{\mathrm{n}} \ldots$ Tense $_{\mathrm{i}}$ AspP VP

Under Gavruseva's approach, 'A Tense Operator cannot bind Tense unless a VP predicate is specified for syntactic aspectual features' (Gavruseva, 2003: 64).

Root infinitives appear when AspP is underspecified, as a tense chain cannot be formed in the absence of Asp. Gavruseva's theory predicts that statives and punctual eventives, which are inherently specified for telicity, licence a tense chain. Non-finite clauses, root infinitives and bare verbs, on the other hand, will be restricted to non-punctual eventive verbs, as they require a grammatical specification of Asp to license a tense chain. These predictions are summarized in (6).

6) a. Prediction 1: Statives (e.g. love) occur in finite contexts.

b. Prediction 2: Punctual eventives (e.g. fall) occur in finite contexts.

c. Prediction 3: Non-punctual eventive verbs (e.g. run) occur in non-finite contexts.

In sum, Gavruseva assumes that early in child L2 acquisition syntactic aspectual heads are underspecified. Thus, the licensing constraint she puts forward predicts that uninflected verbs will be restricted to nonpunctual eventive predicates or aspectually transient verbs since these are contingent on a syntactic specification of Asp to license a tense chain.

\footnotetext{
${ }^{7}$ Following Enç (1987) and Guéron and Hoekstra (1989), Hoekstra and Hyams (1998) assume that in finite clauses there is a connection between a temporal operator situated in the complementizer position and the Tense position, both of which form a tense chain, as shown in (i):
}

(i) $\mathrm{TO}_{\mathrm{i}} \mathrm{F}_{1} \ldots \mathrm{F}_{\mathrm{n}} \ldots$ Tense $_{\mathrm{i}} \mathrm{VP}$.

For Hoekstra and Hyams, if one of the F-nodes in (i) is underspecified, the tense chain is interrupted and becomes invisible, causing the verb to appear as non-finite. On this assumption, then, languages differ in terms of the morphological expressions they use to make the tense chain visible. Some languages express finiteness in terms of tense morphology (Japanese), others through Number (Dutch), and yet others like Italian and Spanish make use of person morphology to express finiteness. 
In the next section, we discuss the child L2 data that will be used as an empirical source for testing the acquisition of tense-aspect morphology with special reference to the distribution of temporal and aspectual interpretation of verb forms in child L2 acquisition of English. We specifically focus on Gavruseva's proposal for root infinitives that ties the distribution of finite and non-finite root predicates to their aspectual features. The longitudinal data consisting of 46 recordings are drawn from spontaneous productions of a 4-year-old Turkish-speaking child L2 learner of English, Erdem. ${ }^{8}$

It should be noted that in contrast to the Missing Surface Inflection Hypothesis, the Truncation Hypothesis and the Underspecification of AspP Hypothesis assume that some categories or features may be underspecified in early L2 syntactic representation. These three approaches are of interest, as they offer different answers to the issue of uninflected verb forms in child L2 acquisition. Unlike Gavruseva's proposal, the Truncation Hypothesis and the Missing Surface Inflection Hypothesis predict that finite and non-finite forms in interlanguage grammars can freely occur with various verb types. For example, they do not predict that Statives and punctual eventives are more likely to occur in finite contexts than other types. This is discussed at length in this study.

\section{The present study}

\section{The participant}

The subject of this study, Erdem, started acquiring English at age 4 in the UK. When data collection started, after one and a half months of exposure to English in a nursery school, he was able to produce some English words, basically the names of animals such as $d o g$, cat and pig. The data analysed in this article consist of 46 recordings, covering a period of approximately 18 months. Apart from the first three sessions, all of the data, collected approximately three times a month, were tape-recorded. Each session was conducted in English and continued for about 40-90 minutes.

\footnotetext{
${ }^{8}$ It should be noted that previous work explored Erdem's L2 English in terms of various issues such as the L2 initial state, the presence or absence of functional categories, and optional infinitives (e.g. Haznedar, 2001; 2003). However, the Aspect hypothesis, the Underspecification hypothesis and the acquisition of temporal-aspectual properties in his L2 English - which are the three main concerns of this article - have not previously been discussed elsewhere.
} 


\section{Data analysis}

Following the coding procedure used in Shirai and Andersen (1995) and Gavruseva (2002), verbs were classified according to aspectual types, stative or eventive, with eventive verbs being further broken down into punctual and non-punctual. In order to make the comparisons visible, we follow Gavruseva (2002; compare Shirai and Andersen, 1995) in that while accomplishments and activities are combined as non-punctual eventives, achievements are taken as punctual eventives. The lexical aspect of the verbs was determined through standard tests for aspect (e.g. Vendler, 1967; Dowty, 1979; Shirai and Andersen, 1995). Only root declarative utterances with a VP predicate are coded as bare or past forms. It is important to note that stative verbs, punctual eventive verbs and nonpunctual eventive verbs are all found in the corpus. Excluded from the analysis were repetitions, imitations and unintelligible utterances. We first investigate the use of past tense morphology in connection with the predictions of the aspect hypothesis.

\section{Results}

\section{Tense marking}

This section examines whether the emergence of tense-aspect morphology is restricted to the aspectual values of verbs. The following questions are addressed in this section:

- What percentage of the verbs/predicates marked for past tense are achievements, accomplishments and activities?

- Are accomplishments gradually marked for past tense?

- Are activities consistently left unmarked?

Appendices 1 and 2 present inflected vs. uninflected verbs with past tense reference by aspectual class. As can be seen in Appendix 1, data on the use of past morphology suggest that past tense forms do not appear at the earliest point in Erdem's L2 English. While the first obligatory past tense context for an irregular verb occurs in Sample 10 (13 June 1994), the earliest appearance of irregular past forms (4/16) is found in Sample 13 (23 Aug 1994). Past tense morphology is first and predominantly used with Achievement verbs. Table 2 presents the percentage of predicates 
marked for past tense by aspectual verb class (Achievements, Accomplishments, Activities).

In Samples 18-31 there are 95 cases of past morphology: $61.05 \%$ (58/95) occurring with Achievement verbs, in comparison to 37 (38.95\%) instances where past tense occurs with non-punctual predicates. Between Samples 32-39, the use of past morphology with Achievements still persists: more than $60 \%$ of the predicates $(61.07 \%)$ occur with Achievements. It is after Sample 40 that the number of instances with non-punctual eventives appears to rise, occurring around $46 \%$. As can be seen in Table 2, non-punctual verbs are marked with past tense but less so than punctual eventives. It is only later that past tense morphology is used with atelic verbs. Some examples of early past morphology are given in (7).

7) a. But my mummy said he not like that.

(Sample 13)

b. I bought it.

(Sample 16)

c. Oh I fell in the water.

(Sample 20)

Overall, we find a gradual development in the suppliance of past morphology with activity and accomplishment verbs. These results are similar to those reported in earlier child L2 acquisition literature (Rohde, 1996; Gavruseva, 2002).

Table 2 Inflected verbs with past tense references by aspectual class

\begin{tabular}{lrrrr}
\hline Sample & \multicolumn{2}{c}{$\begin{array}{c}\text { Punctual eventives } \\
\text { (achievements) }\end{array}$} & \multicolumn{2}{c}{$\begin{array}{c}\text { Non-punctual eventives } \\
\text { (activity 1 accomplishment) }\end{array}$} \\
\hline S 13-17 & $8 / 9$ & $(88.89 \%)$ & $1 / 9$ & $(11 / 11 \%)$ \\
S 18-31 & $58 / 95$ & $(61.05 \%)$ & $37 / 95$ & $(38.95 \%)$ \\
S 32-39 & $91 / 149$ & $(61.07 \%)$ & $58 / 149$ & $(39.93 \%)$ \\
S 40-46 & $124 / 232$ & $(53.45 \%)$ & $108 / 232$ & $(46.55 \%)$ \\
\hline
\end{tabular}

Table 3 Uninflected verbs with past tense references by aspectual class

\begin{tabular}{lrrrr}
\hline Sample & \multicolumn{2}{c}{$\begin{array}{c}\text { Punctual eventives } \\
\text { (achievements) }\end{array}$} & \multicolumn{2}{c}{$\begin{array}{c}\text { Non-punctual eventives } \\
\text { (activity 1 accomplishment) }\end{array}$} \\
\hline S 8-12 & $9 / 26$ & $(34.62 \%)$ & $17 / 26$ & $(65.38 \%)$ \\
S 13-17 & $25 / 50$ & $(50.00 \%)$ & $25 / 50$ & $(50.00 \%)$ \\
S 18-31 & $115 / 183$ & $(62.84 \%)$ & $68 / 183$ & $(37.16 \%)$ \\
S 32-39 & $163 / 224$ & $(72.77 \%)$ & $61 / 224$ & $(27.23 \%)$ \\
S 40-46 & $166 / 259$ & $(64.09 \%)$ & $93 / 259$ & $(35.91 \%)$ \\
\hline
\end{tabular}


Appendix 2 presents the distribution of bare predicates by aspectual verb class in the whole corpus. Table 3 shows that while both punctual and non-punctual predicates are left uninflected in past contexts to varying degrees, in most cases it is the punctual verbs that lack past morphology. In order to make a similar comparison with past inflected verbs, we examine the same time periods in Table 3. In Samples 18-31, of the 183 occurrences of Achievement verbs, 115 of them (62.84\%) are left unmarked. In Samples 32-39, the proportion of uninflected punctuals is even higher (72.77\%) than that of non-punctuals (27.23\%). Overall, we find high rates of uninflected punctuals in the whole corpus. These findings are relevant in the next section where we test Gavruseva's aspectual account of optional infinitives.

A closer examination of the data reveals that the distribution of Erdem's verb types according to presence of past tense morphology could be construed as somewhat consistent with the Aspect Hypothesis between Samples 13-17. That is, his tense marking during this period appears to encode aspectual features such as punctuality rather than temporal distinctions. Recall that according to the Aspect Hypothesis, the Tense projection is argued to be defective at a time when tense morphology is limited to punctual predicates. In other words, if we adopted this line of analysis, we would have to conclude that the early use of verbal morphology patterns by aspectual verb class and, hence, TP is defective in Erdem's L2 grammar. However, evidence for the presence of a TP category in his grammar can come from other sources, such as the use of copula be and auxiliary $d o$. On the assumption that Nominative Case is checked in TP, as in Chomsky (1995), the distribution of pronominal subjects will also inform us about the projection of TP. In what follows, we discuss Erdem's L2 grammar in terms of these TP-related elements.

\section{Is there evidence for defective tense?}

$a$ The emergence of copula be: The copula be was among the first verbs to appear in Erdem's earliest L2 English. We found many utterances with copula be with different predicates. As shown in Appendix 3, despite some occurrences of missing copula be, it is used consistently starting in the second month of the study. Beginning with Sample 8, in particular, which is the third month of data collection, Erdem consistently produces 
sentences with the copula, and its rate is rather high. In Samples 9 and 10, for example, of the 60 copula contexts, 51 have the copula be, $85 \%$. Similarly, in Sample 11 there are 37 copula contexts, and only one utterance lacks the copula be: the rate of be is over $95 \%$. The high incidence of the copula be in Erdem's early utterances suggests the projection of T for tense features. ${ }^{9}$ These results are compatible with the other child L2 studies reported in the literature. Earlier research on child L2 acquisition of English reveals that copula be is acquired early (e.g. Cancino et al., 1974; Dulay and Burt, 1974; Lakshmanan, 1993/94, Gavruseva, 2002).

$b$ The emergence of auxiliary do: As for the development of auxiliary $d o$, the first instances of $d o$-support appear in Sample 9. This is the fourth month of the study and the S-do-support-NEG-V order is consistently produced afterwards.

8) a. I don't like it you mummy

(Sample 9)

b. What do you want?

(Sample 11)

Appendix 4 shows the distribution of $d o$ in negated utterances and questions. In particular starting at Sample 9, which is almost the same period of the high incidence of copula be, we find the consistent use of $d o$-support in obligatory contexts. It should be noted that the placement

\footnotetext{
${ }^{9}$ As pointed out by an anonymous Second Language Research reviewer, the use of copular forms as evidence for the availability of $\mathrm{T}$ is not uncontroversial. A number of researchers have taken the position that the early mastery of be forms can be construed as clear evidence for the presence of $\mathrm{T}$ (e.g. Zobl and Liceras, 1994; Lardiere, 1999; Haznedar, 2001; Gavruseva, 2002; Ionin and Wexler, 2002). In previous work, Haznedar (2001) argues that the presence of be is compelling evidence of I, because be has only functional features; hence, the only reason for be to appear is to support I features (Haznedar, 2001: 23). On similar grounds, Lardiere (1999) points out that mastery of the suppletive agreement paradigm entails that L2 speakers must have an agreement feature-checking mechanism, 'implicating the presence of the associated functional category in the syntactic representation' (Lardiere, 1999: 394). Vainikka and Young-Scholten (1996), on the other hand, argue that the acquisition of suppletive forms does not necessarily reveal knowledge of agreement 'given the potential for acquiring the suppletive forms as unanalysed lexical items' (Vainikka and YoungScholten, 1996: 154). It should be noted, however, that as discussed in (Haznedar, 2001), although early instances of the copula be in Erdem's L2 English predominantly occur with is, all three of the forms am, is and are seem to appear around the same time (e.g. Sample 8). While copula forms with am start in Sample 10 and are used consistently afterwards, copula be with are first appears with the pronoun you in Sample 8 and is used relatively sporadically. Overall, however, it is possible to find both contracted and uncontracted forms even in the same sample during the early stages of acquisition. The following copula examples with am and are come from the third month of Erdem's development where the copula is consistently provided over $90 \%$ of the time:
} 
of the negative element not with respect to the lexical verb is always correct in Erdem's L2 English.

c The use of pronominal subjects: On the assumption that nominative case checking is associated with TP, the realization of Case on pronominal subjects in Erdem's data is also relevant to our discussion. I and you are the first and the most frequently produced nominative pronouns in the corpus.

9) a. I am painting.

(Sample 4)

b. You sleep.

(Sample 5)

The third singular pronouns are also used extensively, although they appear a little later than $I$ and you.

10) a. No \# he is not go nursery. (Sample 12)

b. He just saying I am saying. (Sample 13)

One important finding is that Erdem does not appear to make case errors. Research on L1 acquisition has shown that despite differing rates of errors, English-speaking children make subject pronoun errors, producing non-nominative subjects in addition to nominative subjects (e.g. Vainikka, 1993/94; Rispoli, 1994; Pensalfini, 1995; Powers, 1995; Radford, 1995; Schütze and Wexler, 1996). In Erdem's interlanguage, however, almost all of the pronominal subjects are nominative. There are only three examples in the whole corpus in which the pronominal subject is incorrectly realized in the accusative Case.

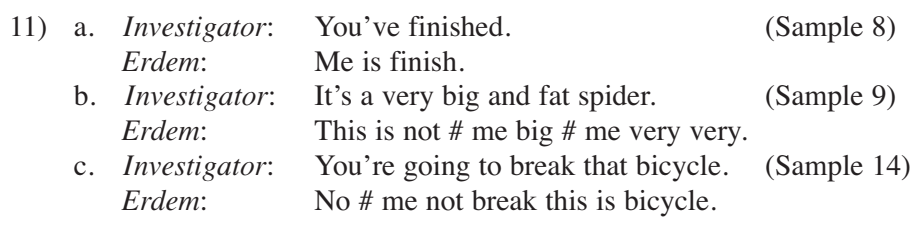

There are a total of 6596 nominative pronouns in nominative contexts. Excluding the second person you, as it is both the nominative and
(i) a. Are you ready?
(Sample 8)
b. Mummy is very funny.
(Sample 9)
c. I'm not hungry.
(Sample 10)

As Lardiere (1999) correctly points out, such findings present a challenge to theoretical models, which assume that syntactic development is contingent on the acquisition of regular verb morphology. 
non-nominative form, there are 5160 opportunities for Erdem to have made a case error on a subject pronoun, and he does not. Thus, Erdem's error rate is extremely low: $3 / 5163(0.06 \%)$. This finding is strikingly different from L1 acquisition facts but compatible with earlier work on child L2 acquisition (e.g. Gavruseva, 2002).

In sum, the correct use of the copula be, do-support and the lack of nonpronominal case errors indicates the availability of TP during a period when the learner uses past tense morphology exclusively on punctual predicates. The next section turns to Gavruseva's predictions presented in (6).

\section{Testing Gavruseva's underspecification of aspect hypothesis}

As has been discussed previously, Gavruseva's Underspecification of Aspect Hypothesis makes specific predictions with regard to the distribution of root infinitives. According to her theory, stative and punctual verbs that are inherently specified for telicity license a tense chain, and hence should appear in finite contexts. Non-finite clauses, root infinitives and bare verbs, on the other hand, are predicted to occur with non-punctual eventives. Our aim in this section is to test these predictions in the light of the child L2 data, some portions of which have already been discussed.

a Prediction 1: Statives occur in finite contexts: The verbs counted as stative include verbs such as know, like and want. We report our findings in Table 4. With regard to the Prediction 1 in (6a), that statives will be finite, Table 4 shows that $58 \%$ of statives are finite. The remaining $42 \%$ of statives in past tense contexts are bare (e.g. He say he like the teddy bear; Sample 23, 29 Nov 1994), contrary to what is predicted in (6a). While one would expect to find more finite statives, we can tentatively conclude that there could be an effect of aspect in regard to the distribution of stative verbs.

Table 4 Finite and uninflected (bare) stative verbs

\begin{tabular}{lll}
\hline & Finite & Bare statives \\
\hline Child & $35 / 60(58 \%)$ & $25 / 60(42 \%)$ \\
\hline
\end{tabular}

b Prediction 2: Punctual eventives occur in finite contexts: Prediction 2 in (6b), that punctual verbs should occur in finite contexts, is not confirmed in the data. As can be seen in Table 5, the proportion of bare punctuals in the corpus is 63\% (478/751), which is rather high. 
We find numerous examples of bare punctual verbs such as those in (12).

12) a. I just finish.

b. I find it.

c. Oh no I fall down.
(Sample 12)

(Sample 18)

(Sample 21)

These results demonstrate that only $37 \%$ of punctual verbs are finite. This is in marked contrast to what is predicted in Gavruseva's model. Clearly, punctual verbs occur in non-finite form. We also examine the distribution of non-punctual verbs in the data.

c Prediction 3: non-punctual eventive verbs occur in non-finite contexts: With regard to Prediction 3 in (6c), we find that while non-punctuals occur in non-finite contexts, as predicted by the model, the proportion of bare non-punctuals is lower than that of bare punctuals. As can be seen in Table 6 , the proportion of bare non-punctuals is 56\% (264/468), as opposed to the $63 \%$ bare punctuals as shown in Table 5. Overall, the proportion of bare punctual verbs is unexpectedly high, and this contrasts with the lower proportion of bare non-punctuals. Gavruseva's Underspecification of AspP Hypothesis does not predict a higher proportion of bare punctuals. On the contrary, bare verbs during the Optional/Root infinitive stage should have been virtually non-punctual eventives. These results are fully compatible with Torrence and Hyams' (2004) study on L1 English. In their analysis of data from Naomi, Nina and Sarah ${ }^{10}$ they also show that the percentage of bare punctuals is much higher than that of uninflected bare nonpunctuals. Overall, we conclude that Gavruseva's underspecification of aspectual features account is not supported by the child L2 data analysed in this article.

Table 5 Inflected (+Finite) vs. uninflected (bare, -Finite) punctual verbs

\begin{tabular}{lll}
\hline & Finite & Bare punctuals \\
\hline Child & $281 / 759(37 \%)$ & $478 / 759(63 \%)$ \\
\hline
\end{tabular}

Table 6 Finite and uninflected (bare) nonpunctual verbs

\begin{tabular}{lll}
\hline & Finite & Bare non-punctuals \\
\hline Child & $204 / 468(44 \%)$ & $264 / 468(56 \%)$ \\
\hline
\end{tabular}

${ }^{10}$ The data are from the CHILDES database (MacWhinney and Snow, 1985). 
To sum up, in this section we have established that neither the Aspect Hypothesis nor Gavruseva's approach to root infinitives appear to account for the child L2 data discussed in this study. The findings reported here lead to the conclusions:

- that while the verb semantics appears to have an effect on the use of early verbal inflection (Achievements being the first to be marked for past tense), evidence from copula be, auxiliary $d o$ and pronominal subjects necessitates the projection of the Tense T; and

- that Gavruseva's approach to root infinitives fails to account for why more punctual verbs remain uninflected in comparison to uninflected non-punctual verbs.

\section{Conclusions}

This study has examined whether the deviant use of verbal inflections in child second language acquisition is consistent with the Aspect Hypothesis and the Underspecification of AspP Hypothesis. We have tested both the aspect-before-tense hypothesis (Bronckart and Sinclair, 1973; Antinucci and Miller, 1976; Andersen and Shirai, 1994; 1996; Shirai and Andersen, 1995) and Gavruseva's aspectual features hypothesis proposed for optional/root infinitives in recent child L2 acquisition (e.g. Gavruseva, 2002; 2003; 2004). On the basis of data from a Turkish-speaking child L2 learner of English, we first focused on the acquisition of past tense morphology and tested specifically whether early emergence of tense-aspect morphology patterns with the semantic/aspectual features of verbs such as punctuality, telicity, etc. We specifically examined the question of whether or not the learner uses past tense morphology exclusively on punctual predicates such as broke, fell and found when inflections first emerge in the data.

As mentioned earlier in Section VI, at first sight the emergent tenseaspect inflections appear to be consistent with the aspect-before-tense hypothesis in particular between Samples 13-17, Achievements being the first to be marked for past tense. Past morphology is then used with atelic verbs. On the basis of these data, one could easily conclude that early L2 grammar is initially underspecified for syntactic tense features. This article, however, has shown that an underspecification approach to T, 
with its emphasis on the deficit in syntactic knowledge, cannot present a complete view of these child L2 data.

On the basis of data from other finiteness markers (e.g. the copula be and auxiliary $d o$ ), it has been shown that even though the use of early verbal inflection is correlated with the verb's lexical aspectual class, the overall picture of finiteness suggests that TP is fully specified in this child's L2 grammar. The results also show that the deviant use of inflections does not follow the predictions of the Underspecification of AspP Hypothesis in root infinitives. While the Underspecification of AspP model attempts to account for a developmental pattern with a focus on the decline of root infinitives in child L2 acquisition, it also raises questions. Some might wonder why punctual verbs presented in this study are mostly non-finite. If uninflected statives, punctuals and non-punctuals are running at the frequencies $42 \%-63 \%-56 \%$, it is not clear how inherent aspectual features play a role. The Underspecification of AspP Hypothesis does not seem to offer any interesting explanation for this distribution.

As discussed in Section IV, Rizzi's (1993/94) theory holds that derivations in adult grammar are subject to the 'Root $=$ CP Principle', suggesting that all clauses project to CP. Early child grammars, on the other hand, are assumed to be underspecified and syntactic structures can be truncated. In contrast, the Missing Surface Inflection Hypothesis assumes a full specification of the syntactic tree and proposes that non-finite predicates in finite contexts result from mapping problems at the syntaxmorphology interface. While the two hypotheses attribute learners' use of non-finite root predicates to different properties of grammar, they make similar developmental predictions in terms of the distribution of finite and non-finite verb forms. Unlike Gavruseva's Underspecification of AspP Hypothesis, both theories predict that finite and non-finite predicates consist of various aspectual verb types. In other words, neither the Truncation Hypothesis nor the Missing Surface Inflection Hypothesis predicts that certain aspectual verb types (e.g. Achievements) are more likely to appear in finite contexts, while other types (e.g. events) appear in non-finite contexts. This is exactly what is found in this study. That is, the results show that the deviant use of verbal morphology does not follow the predictions of the Underspecification of the AspP Hypothesis.

Overall, the analysis of the child L2 data presented in this study raises doubts about: 
- the basic theoretical claims of the Aspect Hypothesis according to which in emergent grammars inflectional verbal morphology denotes the verbs' semantic/aspectual features, rather than deictic tense; and - the specific predictions of the underspecification account of OIs/RIs formulated in Gavruseva's recent work.

For the Aspect Hypothesis to be correct, it would need to be shown not only that the learner restricts PAST to telic eventive verbs, but also that tense is not used appropriately with copula be and auxiliary $d o$, and that pronominal subjects are not appropriately Nominative. For Gavruseva's account to be correct, it would need to be shown that the learner inflects Statives and punctual eventive verbs for tense more than non-punctual eventives, since non-punctual eventives should either not be inflected, or wrongly inflected, as Asp is defective, and a tense chain cannot be constructed. As can be seen, our results clearly show that neither of the above obtain.

It should also be noted that the findings reported in this study are compatible with Rohde's (2002) study, ${ }^{11}$ whose focus is on the deviant use of verbal inflections in the naturalistic acquisition of English by German children. Unlike what is predicted in Gavruseva's model, the analysis of uninflected forms in Rohde's study reveals that the verbs that occur in uninflected past tense contexts are predominantly telic verbs in the form of Achievements and Accomplishments. Some related examples of the omission of past inflection from the Rohde study are given in (13).

13) a. Heiko catch two fish. ACH

b. I just kick him. ACH

c. He jump the right there. $\mathrm{ACH}$

d. You give it already to me. ACH (Rohde, 2002: 206)

Rohde concludes that while the distribution of inflections displays some effect of lexical aspect, compatible with the predictions of the Aspect Hypothesis, the numerous uninflected Achievement verbs are hard to explain in terms of that hypothesis. Rohde also highlights the non-target-like use of verbal inflections in the speech of German child L2 learners of English, suggesting that a number of learner internal or external factors may be influential. Indeed, as has been noted by Rohde (2002) and Salaberry (2002) and others, various other factors might underlie the

\footnotetext{
${ }^{11}$ One should note that Rohde's (2002) study is not concerned with Gavruseva's account of OIs/RIs.
} 
early use of past tense morphology with Achievement verbs (e.g. L1 transfer). On the basis of data from an L1 Spanish learner of English, Robison (1990) discusses the use of inflection with a number of Stative verbs for progressive, which has been attributed to possible L1 transfer of a more general imperfective notion of the progressive marker. We believe that future work should investigate the potential effect of such factors as well as the potential interactions among them.

\section{Acknowledgements}

Earlier versions of this article were presented at GALA (Generative Approaches to Language Acquisition), September 2005, Universitá degli Studi di Siena, Italy, at Universität Hamburg, Germany, January 2006 and at the University of Cambridge, UK, June 2006. Special thanks go to Lydia White, Monika Rothweiler, Melinda Whong-Barr, Teresa Parodi and John Hawkins for their comments and suggestions, as well as to Elena Gavruseva and Roumyana Slabakova for their help with the analysis of verb semantics. Many thanks also Martha Young-Scholten for her support and hospitality during my sabbatical leave at Newcastle University. I am also grateful to two anonymous Second Language Research reviewers for their invaluable suggestions.

\section{References}

Aksu, A. 1978: Aspect and modality in the child's acquisition of the Turkish past tense. PhD dissertation, Department of Psychology, University of California, Berkeley, CA.

Aksu-Koc, A. 1988: The Acquisition of aspect and modality: the case of past reference in Turkish. Cambridge: Cambridge University Press.

— 1998: The role input vs. universal predispositions in the emergence of tense-aspect morphology: evidence from Turkish. First Language 18, $255-80$.

Andersen, R.W. 1991: Developmental sequences: the emergence of aspect marking in second language acquisition. In Huebner, T. and Ferguson, C.A., editors, Crosscurrents in second language acquisition and linguistic theories. Amsterdam/Philadelphia: John Benjamins, 305-24.

Andersen, R.W. and Shirai, Y. 1994: Discourse motivations for some cognitive acquisition principles. Studies in Second Language Acquisition 16: 133-56. 1996: Primacy of aspect in language acquisition. In Ritchie, W. and Bhatia, T., editors, Handbook of second language acquisition. San Diego, CA: Academic Press, 527-70. 
Antinucci, F. and Miller, R. 1976: How children talk about what happened. Journal of Child Language 3, 169-89.

Bach, E. 1986: The algebra of events. Linguistics and Philosophy 9, 5-16.

Bardovi-Harlig, K. 1995: A narrative perspective on the development of the tense-aspect system in second language acquisition. Studies in Second Language Acquisition 17, 263-91.

1998: Narrative structure and lexical aspect: conspiring factors in second language acquisition of tense-aspect morphology. Studies in Second Language Acquisition 20, 471-508.

Bardovi-Harlig, K. and Bergström, A. 1996: The acquisition of tense and aspect in second language and foreign language learning: learner narratives in English (SL) and French (FL). Canadian Modern Language Review 52, 308-30.

Bardovi-Harlig, K. and Reynolds, D.W. 1995: The role of lexical aspect in the acquisition of tense and aspect. TESOL Quarterly 29, 107-31.

Behrens, H. 2001: Cognitive-conceptual development and the acquisition of grammatical morphemes: the development of time concepts and verb tense. In Bowermann, M. and Levinson, S.C., editors, Language acquisition and conceptual development. Cambridge: Cambridge University Press, 450-74.

Bickerton, D. 1975: Dynamics of a creole system. Cambridge: Cmabridge University Press.

1984: The language bioprogram hypothesis. Behavioral and Brain Sciences 7, 173-88.

Bloom, L., Lifter, K. and Hafitz, J. 1980: Semantics of verbs and the development of verb inflection in child language. Language 56, 386-412.

Borer, H. 1994: The projection of arguments. In Benedicto, E. and Runner, J., editors, University of Massachussetts Occasional Papers in Linguistics 17, Amherst, MA: Graduate Linguistic Student Association, 19-47.

Bromberg, H. and Wexler, K. 1995: Null subjects in child wh-questions. MIT Working Papers in Linguistics 26, 221-47.

Bronckart, J.P. and Sinclair, H. 1973: Time, tense and aspect. Cognition 2, 107-30.

Brown, R. 1973: A first language. Cambridge, MA: Harvard University Press.

Cancino, H., Rosansky, E. and Schumann, J. 1974: Testing hypotheses about second language acquisition: the copula and the negative in three subjects. Working Papers in Bilingualism 3, 80-96.

Chomsky, N. 1995: The minimalist program. Cambridge, MA: MIT Press.

Comrie, B. 1976: Aspect. Cambridge: Cambridge University Press.

de Haan, G. 1986: A theory-bound approach to the acquisition of verb-placement in Dutch. In de Haan, G. and Zonneveld, W., editors, Formal parameters of generative grammar. Dordrecht: Foris, 15-30.

de Swart, H. 1998: Aspect shift and coercion. Natural Language and Linguistic Theory 16, 347-85.

Dowty, D. 1979: Word meaning and Montague grammar. Dordrecht: Reidel. 
Dulay, H.C. and Burt, M.K. 1974: Natural sequences in child second language strategies. Language Learning 24, 37-53.

Dulay, H.C. and Burt, M.K. and Krashen, S. 1982: Language two. New York: Oxford University Press.

Enç, M. 1987: Anchoring conditions for tense. Linguistic Inquiry 18, 633-57.

Ferdinand, A. 1996: The acquisition of the subject in French. Unpublished PhD dissertation, Holland Institute of Generative Linguistics, Leiden University.

Gavruseva, E. 2002: Is there primacy of aspect in child L2 English? Bilingualism: Language and Cognition 5 (2), 109-30.

- 2003: Aktionsart, aspect and the acquisition of finiteness in early child grammar. Linguistics 41, 723-55.

- 2004: Root infinitives in child second language English: an aspectual features account. Second Language Research 20, 335-71.

Gavruseva, E. and Lardiere, D. 1996: The emergence of extended phrase structure in child L2 acquisition. In Stringfellow, A., Cahana-Amitay, D., Hughes, E. and Zukowski, A., editors, Proceedings of the 20th Annual Boston University Conference on Language Development. Somerville, MA: Cascadilla Press, 225-36.

Grondin, N. and L. White. 1996: Functional categories in child L2 acquisition of French. Language Acquisition 1, 1-34.

Guéron, J. and Hoekstra, T. 1989: The chains and constituent structure of auxiliaries. In Cardinaletti, A., Cinque, G. and Giusti, G., Constituent structure: Papers from the Venice GLOW, 35-99. Dordrecht: Foris.

- 1995: The temporal interpretation of predication. In Cardinaletti, A. and Guasti, M.T., editors, Small clauses, syntax and semantics, 28, 77-107.

Haznedar, B. 2001: The acquisition of the IP system in child L2 acquisition. Studies in Second Language Acquisition 23, 1-39.

2003: The status of functional categories in child second language acquisition: evidence from the acquisition of CP. Second Language Research $19,1-41$.

Haznedar, B. and Schwartz, B.D. 1997: Are there Optional Infinitives in child L2 acquisition? In Hughes, E., Hughes, M. and Greenhill, A., editors, Proceedings of the 21 st Annual Boston University Conference on Language Development. Somerville, MA: Cascadilla Press, 257-68.

Hoekstra, T. and Hyams, N. 1995: The syntax and interpretation of dropped categories in child language: a unified account. Proceedings of the West Coast Conference on Formal Linguistics 14. Stanford, CA: CSLI, 123-36.

— 1996: Missing heads in child language. In Koster, C. and Wijnen, F., editors, Proceedings of the Generative Approaches to Language Acquisition conference 1995. Groningen: Center for Language and Cognition, 251-60. 1998: Aspects of root infinitives. Lingua 106, 81-112.

Hoekstra, T., Hyams, N. and Becker, M. 1996: The underspecification of Number and the licensing of root infinitives. In Stringfellow, A., CahanaAmitay, D., Hughes, E. and Zukowski, A., editors, Proceedings of the 
20th Annual Boston University Conference on Language Development. Somerville, MA: Cascadilla Press, 293-306.

Ionin, T. and Wexler, K. 2002: Why is 'is' easier than '-s'?: acquisition of tense-agreement morphology by child second language learners of English. Second Language Research 18, 95-136.

Lakshmanan, U. 1993/94: The boy for the cookie: some evidence for the nonviolation of the Case Filter in child second language acquisition. Language Acquisition 3, 51-97.

Lakshmanan, U. 1994: Universal Grammar in child second language acquisition. Amsterdam: John Benjamins.

Lardiere, D. 1998: Case and Tense in the 'fossilized' steady state. Second Language Research 14, 1-26.

- 1999: Suppletive agreement in second language acquisition. In Greenhill, A., Littlefield, H. and Tano, C., editors, Proceedings of the 21 st Annual Boston University Conference on Language Development. Somerville, MA: Cascadilla Press, 386-39.

— 2000: Mapping features to forms in second language acquisition. In Archibald, J., editor, Second language acquisition and linguistic theory, Oxford: Blackwell, 103-29.

MacWhinney, B. and Snow, C. 1985: The child language data exchange system. Journal of Child Language 12, 271-96.

Paradis, J., LeCorre, M. and Genesee, F. 1998: The emergence of tense and agreement in child L2 French. Second Language Research 14, 227-57.

Pensalfini, R. 1995: Pronoun case errors, both syntactic and morphological. MIT Working Papers in Linguistics 26, 305-24.

Powers, S.M. 1995: The acquisition of pronouns in Dutch and English: the case for Continuity. In MacLaughlin, D. and McEwen, S., editors, Proceedings of the 19th Annual Boston University Conference on Language Development 19. Somerville, MA: Cascadilla Press, 439-50.

Prévost, P. 1997: Truncation and Root Infinitives in second language acquisition of French. In Hughes, E., Hughes, M. and Greenhill, A., editors, Proceedings of the 21st Annual Boston University Conference on Language Development. Somerville, MA: Cascadilla Pres, 21, 453-64.

Prévost, P. and White, L. 2000: Missing surface inflection or impairment in second language? Evidence from Tense and Agreement. Second Language Research 16, 103-33.

Radford, A. 1995: Children-architects or brickies? In MacLaughlin, D. and McEwen, S., editors, Proceedings of the 19th Annual Boston University Conference on Language Development 19. Somerville, MA: Cascadilla Press, 1-19.

Rispoli, M. 1994: Pronoun case overextensions and paradigm building. Journal of Child Language 21, 157-72.

Rizzi, L. 1993/94: Some notes on linguistic theory and language development: the case of root infinitives. Language Acquisition 3, 371-93. 
1994: Early null subjects and root null subjects. In Hoekstra, T. and Schwartz, B.D., editors, Language Acquisition Studies in Generative Grammar. Amsterdam: John Benjamins, 151-76.

Robison, R.E. 1990: The primacy of aspect: aspectual marking in English interlanguage. Studies in Second Language Acquisition 12, 315-30.

— 1995: The Aspect Hypothesis revisited: a cross-sectional study of tense and aspect marking in interlanguage. Applied Linguistics 16, 344-70.

Rohde, A. 1996: The aspect hypothesis and the emergence of tense distinctions in naturalistic L2 acquisition. Linguistics 34, 1115-37.

- 2002: The aspect hypothesis in naturalistic L2 acquisition: what uninflected and non-target-like verb forms in early interlanguage tell us. In Salaberry, R. and Shirai, Y., editors, The L2 acquisition of tense-aspect morphology. Amsterdam: John Benjamins, 199-220.

Salaberry, R. 2002: Tense and aspect in the selection of Spanish past tense verbal morphology. In Salaberry, R. and Shirai, Y., editors, The L2 acquisition of tense-aspect morphology. Amsterdam: John Benjamins, 397-415.

Sano, T. and Hyams, N. 1994: Agreement, finiteness, and the development of null arguments. Proceedings of the North Eastern Linguistic Society 24, Amherst, Graduate Linguistic Student Association, 543-58.

Schlyter, S. 1990: The acquisition of tense and aspect. In Meisel, J., editor, Two first languages: Early grammatical development in bilingual children. Dordrecht: Foris, 87-121.

Schütze, C.T. and Wexler, K. 1996: Subject case licensing and English root infinitives. In Stringfellow, A., Cahana-Amitay, D., Hughes, E. and Zukowski, A., editors, Proceedings of the 20th Annual Boston University Conference on Language Development. Somerville, MA: Cascadilla Press, $670-81$.

Shirai, Y. 1998: The emergence of tense-aspect morphology in Japanese: universal disposition. First Language 18, 281-310.

Shirai, Y. and Andersen, R.W. 1995: The acquisition of tense-aspect morphology: a prototype account. Language 71, 743-62.

Slabakova, R. 1999: The parameter of aspect in second language acquisition. Second Language Research 15, 283-317.

2001: Telicity in the second language. Amsterdam: John Benjamins.

Slobin, D.I. 1985: Crosslinguistic evidence for the language-making capacity. In Slobin, D.I., editor, The crosslinguistic study of language acquisition: theoretical Issues, volume 2. Hillsdale, NJ: Lawrence Erlbaum.

Smith, C.S. 1983: A theory of aspectual choice. Language, 59: 479-501. 1991 [1997]: The parameter of aspect. Dordrecht: Kluwer.

Suppes, P. 1973: The semantics of children's language. American Psychologist 88, 103-14.

Torrence, H. and Hyams, N. 2004: On the role of aspect in determining Finiteness and Temporal interpretation of early grammar. Proceedings of 
the Generative Approaches to Language Acquisition conference 10, Landelijke Onderzoekschool Taalwetenschap (LOT). Utrecht: University of Utrecht.

Travis, L. 1991: Derived objects, inner aspect and the structure of VP. Unpublished paper presented at North Eastern Linguistic Society, University of Delaware, Newark, DE.

Vainikka, A. 1993/94: Case in the development of English syntax. Language Acquisition 3, 257-325.

Vainikka, A. and Young-Scholten, M. 1996: The early stages in adult L2 syntax: additional evidence from Romance speakers. Second Language Research 12, 140-46.

Vendler, Z. 1967: Verbs and times. Philosophical Review 56, 143-60.

Verkuyl, H. 1972: On the compositional nature of the aspects. Dordrecht: Reidel.

— 1989: Aspectual classes and aspectual composition. Linguistics and Philosophy 12: 39-94.

Wexler, K. 1994: Optional Infinitives, head movement and the economy of derivations. In Lightfoot, D. and Hornstein, N., editors, Verb movement. Cambridge: Cambridge University Press, 305-50.

White, L. 2003: Fossilization in steady state L2 grammars: persistent problems with inflectional morphology. Bilingualism: Language and Cognition 6, 129-41.

Wijnen, F. 1996: Temporal reference and eventivity in root infinitives. MIT Occasional Papers in Linguistics 12, 1-25.

Zobl, H. and Liceras, J. 1994: Functional categories and acquisition orders. Language Learning 44, 159-80. 
Appendix 1 Inflected verbs with past tense references by aspectual class

\begin{tabular}{|c|c|c|c|c|}
\hline \multirow[t]{2}{*}{ Sample } & \multirow{2}{*}{$\begin{array}{l}\text { Punctual eventives } \\
\text { Achievement } \\
\text { verbs }\end{array}$} & \multicolumn{2}{|c|}{ Non-punctual eventives } & \multirow[b]{2}{*}{ Statives } \\
\hline & & $\begin{array}{l}\text { Accomplishment } \\
\text { verbs }\end{array}$ & $\begin{array}{l}\text { Activity } \\
\text { verbs }\end{array}$ & \\
\hline S 13 & said (3) & $\operatorname{did}(1)$ & & \\
\hline S 14 & & & & \\
\hline S 15 & died (1) & & & \\
\hline S 16 & broke (2) brought & & & \\
\hline S 17 & finished & & & \\
\hline S 18 & & & $\begin{array}{l}\text { played (5), } \\
\text { painted }\end{array}$ & \\
\hline S 19 & & & & \\
\hline S 20 & $\begin{array}{l}\text { said, fell (2), } \\
\text { died (1), scared }\end{array}$ & $\operatorname{did}(3)$ & & \\
\hline S 21 & & 0 & & \\
\hline S 22 & $\begin{array}{l}\text { found, fell (2), } \\
\text { bought }\end{array}$ & did & & \\
\hline S 23 & $\begin{array}{l}\text { said (3), } \\
\text { found (4) }\end{array}$ & $\operatorname{did}(2)$ & & \\
\hline S 24 & left & $\operatorname{did}(4)$ & & \\
\hline S 25 & found, took, told & & & \\
\hline S 26 & said & made (5) & & \\
\hline S 27 & broke, told & did & & \\
\hline S 28 & $\begin{array}{l}\text { bought, broke, } \\
\text { said (4) }\end{array}$ & did & & \\
\hline S 29 & $\begin{array}{l}\text { said (5) lost, } \\
\text { found (2) }\end{array}$ & $\begin{array}{l}\text { made (3), } \\
\text { happened, } \\
\text { did }\end{array}$ & & \\
\hline S 30 & $\begin{array}{l}\text { told }(3), \text { said }(2), \\
\text { found told }(6), \\
\text { said }(3), \text { broke, }\end{array}$ & made (6) & & \\
\hline S 31 & $\begin{array}{l}\text { took, brought (2), } \\
\text { found, crashed }\end{array}$ & $\operatorname{did}(3)$ & & \\
\hline S 32 & $\begin{array}{l}\text { said (6), broke, told, } \\
\text { met (2), sat }\end{array}$ & & & \\
\hline S 33 & $\begin{array}{l}\text { said }(8), \text { bought, } \\
\text { came }(2), \text { found, } \\
\text { died }\end{array}$ & $\begin{array}{l}\text { wrote }(3) \\
\text { made }(8)\end{array}$ & & \\
\hline S 34 & $\begin{array}{l}\text { brought, broke (2), } \\
\text { said, }\end{array}$ & made (7) & & \\
\hline S 35 & $\begin{array}{l}\text { said, met (3), lost, } \\
\text { found, stopped }\end{array}$ & & & \\
\hline S 36 & $\begin{array}{l}\text { said (12), saw, told } \\
\text { broke, left, said (7), }\end{array}$ & made (10) & & wanted \\
\hline S 37 & $\begin{array}{l}\text { came (1), caught (2), } \\
\text { took } \\
\text { said (9), saw, waked }\end{array}$ & made (7) & helped & \\
\hline S 38 & $\begin{array}{l}\text { up (2), stopped, } \\
\text { jumped }\end{array}$ & made (5) & $\begin{array}{l}\text { went (3), } \\
\text { laughed }\end{array}$ & had \\
\hline S 39 & $\begin{array}{l}\text { lost, came, broke (3), } \\
\text { found (2), fell (2), } \\
\text { said (3), saw (2), } \\
\text { dropped }\end{array}$ & $\begin{array}{l}\text { made (8), } \\
\text { moved, } \\
\text { decided }\end{array}$ & cried (3) & $\begin{array}{l}\text { had (2), } \\
\text { thought }\end{array}$ \\
\hline
\end{tabular}




\section{The acquisition of tense-aspect in child L2 English}

Appendix 1 (continued)

\begin{tabular}{|c|c|c|c|c|}
\hline \multirow[t]{2}{*}{ Sample } & \multirow{2}{*}{$\begin{array}{l}\text { Punctual eventives } \\
\text { Achievement } \\
\text { verbs }\end{array}$} & \multicolumn{2}{|c|}{ Non-punctual eventives } & \multirow[b]{2}{*}{ Statives } \\
\hline & & $\begin{array}{l}\text { Accomplishment } \\
\text { verbs }\end{array}$ & $\begin{array}{l}\text { Activity } \\
\text { verbs }\end{array}$ & \\
\hline S 40 & $\begin{array}{l}\text { came, said, } \\
\text { bringed, } \\
\text { breaked }\end{array}$ & $\begin{array}{l}\operatorname{did}(3), \\
\text { made (6) }\end{array}$ & wanted (2) & \\
\hline S 41 & $\begin{array}{l}\text { said (4), saw (3), } \\
\text { fell, told, came ( } 2) \text {, } \\
\text { lost, found, } \\
\text { looked }\end{array}$ & $\begin{array}{l}\text { made (5), } \\
\text { did, went (4) }\end{array}$ & $\begin{array}{l}\text { helped (2), } \\
\text { played (5), } \\
\text { worked (2), }\end{array}$ & wanted \\
\hline S 42 & $\begin{array}{l}\text { found, saw (2), } \\
\text { said (2) }\end{array}$ & 0 & did & had (2) \\
\hline S 43 & $\begin{array}{l}\text { said (13), left, } \\
\text { fell (2), saw ( } 3), \\
\text { died, dropped, } \\
\text { blowed down }\end{array}$ & $\begin{array}{l}\operatorname{did}(2), \\
\text { went (3), } \\
\text { made (4) }\end{array}$ & $\begin{array}{l}\text { opened (2), } \\
\text { speaked (3), } \\
\text { runned }\end{array}$ & $\begin{array}{l}\text { wanted, } \\
\text { knowed, } \\
\text { had } \\
\text { thinked, }\end{array}$ \\
\hline S 44 & $\begin{array}{l}\text { said (13), told (2), } \\
\text { found (2), saw, } \\
\text { switched off }\end{array}$ & $\begin{array}{l}\text { went, made, } \\
\text { did ( } 2 \text { ) } \\
\text { climbed up }\end{array}$ & $\begin{array}{l}\text { made (2), } \\
\text { played (4), } \\
\text { turn }\end{array}$ & $\begin{array}{l}\text { wanted (4), } \\
\text { had (2) }\end{array}$ \\
\hline S 45 & $\begin{array}{l}\text { said (4), found, } \\
\text { oppened, stopped } \\
\text { found (6), said (23), }\end{array}$ & $\begin{array}{l}\text { made (3), did, } \\
\text { went (3) }\end{array}$ & went (4), & $\operatorname{had}(7)$ \\
\hline S 46 & $\begin{array}{l}\text { saw }(7) \text {, told (4), } \\
\text { broke, lost, stole, } \\
\text { jumped ( } 5) \text {, } \\
\text { breaked (2), kill (3) }\end{array}$ & $\begin{array}{l}\text { did, went (19), } \\
\text { made (8), }\end{array}$ & $\begin{array}{l}\text { went (4), } \\
\text { watched (3), } \\
\text { played (4), } \\
\text { talked }\end{array}$ & $\begin{array}{l}\text { had (7), } \\
\text { thought (3) }\end{array}$ \\
\hline
\end{tabular}

Appendix 2 Uninflected verbs with past tense references by aspectual class

\begin{tabular}{|c|c|c|c|c|}
\hline \multirow[b]{2}{*}{ Sample } & \multirow{2}{*}{$\begin{array}{l}\text { Punctual eventives } \\
\text { Achievement } \\
\text { verbs }\end{array}$} & \multicolumn{2}{|c|}{ Non-punctual eventives } & \multirow[b]{2}{*}{ Statives } \\
\hline & & $\begin{array}{l}\text { Accomplishment } \\
\text { verbs }\end{array}$ & Activity verbs & \\
\hline \multicolumn{5}{|l|}{$\mathrm{S}$} \\
\hline $1-7$ & 0 & 0 & 0 & \\
\hline $\begin{array}{l}\text { S } 8 \\
\text { S } 9\end{array}$ & look & watch & & \\
\hline S 10 & come & go (2) & $\begin{array}{l}\text { play (3) } \\
\text { do (2) }\end{array}$ & \\
\hline S 11 & see, finish & & play (3) & \\
\hline S 12 & $\begin{array}{l}\text { finish, come, } \\
\text { see, say (2) }\end{array}$ & go & $\begin{array}{l}\text { play }(3), \\
\text { run, swim }\end{array}$ & \\
\hline S 13 & $\begin{array}{l}\text { buy, come, } \\
\text { say, sit, do } 9(2)\end{array}$ & go (5) & $\begin{array}{l}\text { play (3), } \\
\text { talk (2), runs }\end{array}$ & \\
\hline S 14 & say, & & & \\
\hline S 15 & come, say (9) & do (2) & eat (2), play & \\
\hline S 16 & $\begin{array}{l}\text { look, buy, } \\
\text { get, say }\end{array}$ & make & eat & \\
\hline S 17 & $\begin{array}{l}\text { come, say (2), } \\
\text { finish }\end{array}$ & $\begin{array}{l}\text { do (3), } \\
\text { go (2) }\end{array}$ & eat, colour & \\
\hline S 18 & $\begin{array}{l}\text { find, get (2), } \\
\text { say, show }\end{array}$ & do (6) & $\begin{array}{l}\text { play, } \\
\text { colour (4) }\end{array}$ & \\
\hline
\end{tabular}


Appendix 2 (continued)

\begin{tabular}{|c|c|c|c|c|}
\hline \multirow[b]{2}{*}{ Sample } & \multirow{2}{*}{$\begin{array}{l}\text { Punctual eventives } \\
\text { Achievement } \\
\text { verbs }\end{array}$} & \multicolumn{2}{|c|}{ Non-punctual eventives } & \multirow[b]{2}{*}{ Statives } \\
\hline & & $\begin{array}{l}\text { Accomplishment } \\
\text { verbs }\end{array}$ & Activity verbs & \\
\hline S 18 & $\begin{array}{l}\text { find, get (2), } \\
\text { say, show }\end{array}$ & do $(6)$ & $\begin{array}{l}\text { play, } \\
\text { colour (4) }\end{array}$ & \\
\hline S 19 & $\begin{array}{l}\text { look (2), } \\
\text { say (2) }\end{array}$ & $\begin{array}{l}\text { paint, } \\
\text { do (7), go }\end{array}$ & & \\
\hline S 20 & $\begin{array}{l}\text { get }(2) \text {, say }(3) \text {, } \\
\text { shoot }(2), \\
\text { finish }(2), \\
\text { look, pass }\end{array}$ & $\begin{array}{l}\text { do (7), go, } \\
\text { write (3), } \\
\text { watch (2) }\end{array}$ & play & \\
\hline S 21 & $\begin{array}{l}\text { finish, bring, } \\
\text { fall, get, say (2) }\end{array}$ & play (5) & make & \\
\hline S 22 & $\begin{array}{l}\text { bring (3), come, } \\
\text { say (4), ask, } \\
\text { finish (2), } \\
\text { jump (2) }\end{array}$ & $\begin{array}{l}\text { do (2), } \\
\text { play }\end{array}$ & $\begin{array}{l}\text { drink, } \\
\text { eat }(2) \text {, } \\
\text { colour }\end{array}$ & \\
\hline S 23 & $\begin{array}{l}\text { look, show, } \\
\text { bring, come, } \\
\text { find, get, } \\
\text { say (3), } \\
\text { see (2) }\end{array}$ & $\begin{array}{l}\text { do (3), } \\
\text { go (2) }\end{array}$ & cry, draw & like (3) \\
\hline S 24 & $\begin{array}{l}\text { finish (2), } \\
\text { happen, } \\
\text { give (4), } \\
\text { say (2), look }\end{array}$ & do (4), go & eat & \\
\hline S 25 & $\begin{array}{l}\text { bring (2), } \\
\text { buy, fall, get, } \\
\text { say, tell, win, } \\
\text { close, turn }\end{array}$ & & & \\
\hline S 26 & $\begin{array}{l}\text { come (3), } \\
\text { say }(4) \text {, see }\end{array}$ & & & \\
\hline S 27 & $\begin{array}{l}\text { give (2), } \\
\text { finish }\end{array}$ & $\begin{array}{l}\text { do }(3) \text {, } \\
\text { learn }\end{array}$ & colour, & \\
\hline S 28 & $\begin{array}{l}\text { say }(6), \\
\text { ask (2), } \\
\text { cough (2), } \\
\text { touch }\end{array}$ & do & & \\
\hline S 29 & $\begin{array}{l}\text { finish (2), } \\
\text { get, see (2), } \\
\text { tell }\end{array}$ & & & \\
\hline S 30 & $\begin{array}{l}\text { wake, win } \\
\text { come, find, } \\
\text { get, give (2), } \\
\text { say (4), see (2), } \\
\text { crash, }\end{array}$ & do & & \\
\hline S 31 & pick (2) & do & $\begin{array}{l}\text { draw, } \\
\text { laugh, } \\
\text { play }\end{array}$ & \\
\hline S 32 & $\begin{array}{l}\text { buy, come (3), } \\
\text { fall (2), get (2), } \\
\text { give, say ( } 2) \text {, } \\
\text { die, stop }\end{array}$ & go, do & $\begin{array}{l}\text { eat (2), } \\
\text { make (2), } \\
\text { write, } \\
\text { wash, try }\end{array}$ & \\
\hline
\end{tabular}




\section{The acquisition of tense-aspect in child L2 English}

Appendix 2 (continued)

\begin{tabular}{|c|c|c|c|c|}
\hline \multirow[b]{2}{*}{ Sample } & \multirow{2}{*}{$\begin{array}{l}\text { Punctual eventives } \\
\text { Achievement } \\
\text { verbs }\end{array}$} & \multicolumn{2}{|c|}{ Non-punctual eventives } & \multirow[b]{2}{*}{ Statives } \\
\hline & & $\begin{array}{l}\text { Accomplishment } \\
\text { verbs }\end{array}$ & Activity verbs & \\
\hline S 33 & $\begin{array}{l}\text { close, crash (2), } \\
\text { jump (2), show, } \\
\text { look, buy ( } 2) \text {, } \\
\text { come, fall, find, } \\
\text { get ( } 3 \text { ), give (2), } \\
\text { say, shoot, take (2), } \\
\text { throw }\end{array}$ & go (4), park & $\begin{array}{l}\text { watch (2) } \\
\text { draw, } \\
\text { drive, } \\
\text { eat, } \\
\text { make }\end{array}$ & \\
\hline S 34 & $\begin{array}{l}\text { buy, give, take, } \\
\text { throw (3) }\end{array}$ & go, talk & $\begin{array}{l}\text { eat, run, } \\
\text { stay, watch, } \\
\text { decide }\end{array}$ & \\
\hline S 35 & $\begin{array}{l}\text { shoot (2), throw, } \\
\text { stick break, buy (2) } \\
\text { get (4), give (3), } \\
\text { say (2), see, tell, } \\
\text { ask, crash (2), } \\
\text { press, }\end{array}$ & do (2) & & like (2) \\
\hline S 36 & $\begin{array}{l}\text { show, look (2) } \\
\text { finish, show (2), } \\
\text { stop (2), decide, } \\
\text { buy, come (3), } \\
\text { get (4), give, } \\
\text { say (2), stick, }\end{array}$ & go (2) & & like (2) \\
\hline S 37 & throw $(3)$, win & go (5) & $\begin{array}{l}\text { eat, } \\
\text { kiss, } \\
\text { write }\end{array}$ & think (2) \\
\hline S 38 & $\begin{array}{l}\text { catch (2), } \\
\text { come (4), } \\
\text { fall, get, give, } \\
\text { say (2), see, } \\
\text { throw (2), } \\
\text { close (2), } \\
\text { drop, press (2), } \\
\text { look, open, } \\
\text { stay }\end{array}$ & go (2), do & $\begin{array}{l}\text { grow, } \\
\text { try (3), } \\
\text { paint, } \\
\text { watch }\end{array}$ & \\
\hline S 39 & $\begin{array}{l}\text { close, jump, } \\
\text { show, splash (2), } \\
\text { spoil, turn, stay, } \\
\text { open (2), buy (4), } \\
\text { come (7), get (6), } \\
\text { give (3), hold, say (2), } \\
\text { see, shoot (2) }\end{array}$ & $\begin{array}{l}\text { cook, } \\
\text { carry, do (2), } \\
\text { go (6) }\end{array}$ & $\begin{array}{l}\text { cry, } \\
\text { wash, } \\
\text { eat }\end{array}$ & think (2) \\
\hline S 40 & $\begin{array}{l}\text { bring, buy (2), } \\
\text { come (3), fall, } \\
\text { get }(4) \text {, give, } \\
\text { hear, crash ( } 2) \text {, } \\
\text { kick, change, } \\
\text { open }\end{array}$ & $\begin{array}{l}\text { do }(4), \\
\text { go }(2), \\
\text { learn }\end{array}$ & $\begin{array}{l}\text { drink (3), } \\
\text { make, } \\
\text { cry (2) }\end{array}$ & \\
\hline S 41 & $\begin{array}{l}\text { call, kill, start, } \\
\text { fill, lift, look (2), } \\
\text { open, bring, }\end{array}$ & $\begin{array}{l}\text { go (3), } \\
\text { learn, } \\
\text { fly }\end{array}$ & make & want (3) \\
\hline
\end{tabular}


Appendix 2 (continued)

\begin{tabular}{|c|c|c|c|c|}
\hline \multirow[b]{2}{*}{ Sample } & \multirow{2}{*}{$\begin{array}{l}\text { Punctual eventives } \\
\text { Achievement } \\
\text { verbs }\end{array}$} & \multicolumn{2}{|c|}{ Non-punctual eventives } & \multirow[b]{2}{*}{ Statives } \\
\hline & & $\begin{array}{l}\text { Accomplishment } \\
\text { verbs }\end{array}$ & Activity verbs & \\
\hline & $\begin{array}{l}\text { get (7), give, } \\
\text { hold, say (4), } \\
\text { take, throw (3) }\end{array}$ & & & \\
\hline S 42 & $\begin{array}{l}\text { get (2), give, } \\
\text { say, take, } \\
\text { stick, look }\end{array}$ & go (3), do & $\begin{array}{l}\text { eat } \\
\text { learn } \\
\text { laugh }\end{array}$ & know (2) \\
\hline S 43 & $\begin{array}{l}\text { pull (2), turn, } \\
\text { come, get (3), } \\
\text { hear, meet (4), } \\
\text { say, speak (4), } \\
\text { tell }\end{array}$ & go (6) & $\begin{array}{l}\text { try, } \\
\text { play, } \\
\text { run }\end{array}$ & know (3) \\
\hline 1S 44 & $\begin{array}{l}\text { bring, buy, } \\
\text { come, hold, } \\
\text { say, stand, } \\
\text { tell, throw, } \\
\text { call, open }\end{array}$ & $\begin{array}{l}\text { do (3), } \\
\text { go (2) }\end{array}$ & $\begin{array}{l}\text { draw (2), } \\
\text { play, climb, } \\
\text { stay }\end{array}$ & like (2) \\
\hline S 45 & $\begin{array}{l}\text { come (2), } \\
\text { find (2), give, } \\
\text { hold (2), see (2) }\end{array}$ & $\begin{array}{l}\text { go (11), } \\
\text { plant }\end{array}$ & eat (2) & \\
\hline S 46 & $\begin{array}{l}\text { bring (2), } \\
\text { buy (10), } \\
\text { catch (3), } \\
\text { come, fall (3), } \\
\text { get, give (18), } \\
\text { hold, leave, } \\
\text { ring, see (3), } \\
\text { sit, stand, } \\
\text { stick (6), } \\
\text { take (2), } \\
\text { tell, win, } \\
\text { call, jump, } \\
\text { kill, pick, } \\
\text { pull (2), } \\
\text { taste, } \\
\text { touch (4), } \\
\text { look (3), } \\
\text { open (2) }\end{array}$ & do (3) & $\begin{array}{l}\text { drink, drive, } \\
\text { eat (8), feed, } \\
\text { sing, sleep (3), } \\
\text { climb (2), } \\
\text { colour (2), } \\
\text { cook, cry, } \\
\text { play (2), } \\
\text { watch (5) }\end{array}$ & think (3) \\
\hline
\end{tabular}




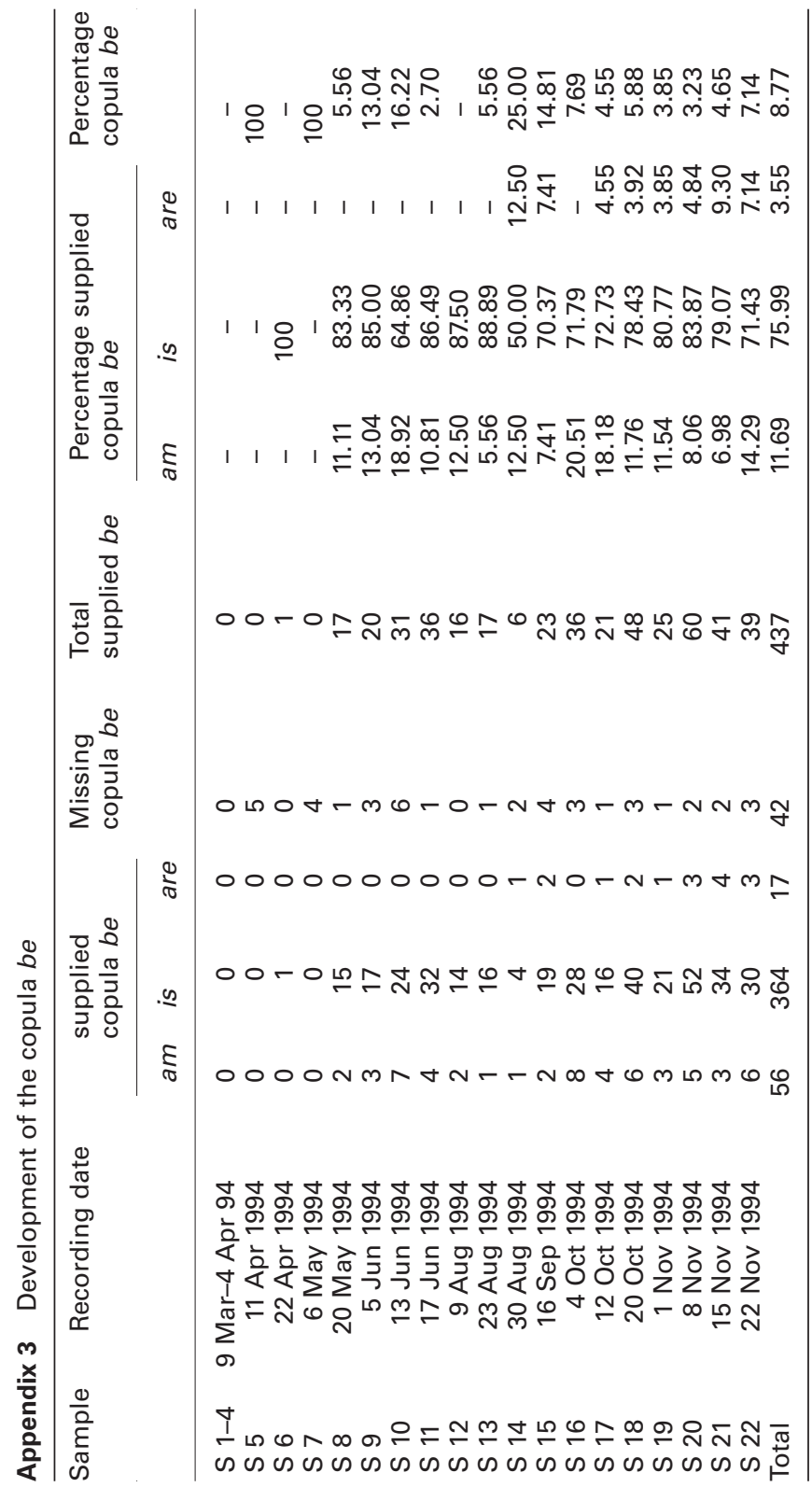


Appendix 4 Do-support in negatives and questions

\begin{tabular}{|c|c|c|c|c|c|}
\hline Sample & $\begin{array}{l}\text { do- } \\
\text { support }\end{array}$ & $\begin{array}{l}\text { missing } \\
\text { do }\end{array}$ & Total & $\begin{array}{l}\text { Percentage } \\
\text { do }\end{array}$ & $\begin{array}{l}\text { Percentage } \\
\text { missing do }\end{array}$ \\
\hline S 1-5 & 0 & 0 & 0 & - & - \\
\hline S 6 & 2 & 0 & 2 & 100 & 0 \\
\hline S 7 & 0 & 0 & 0 & - & - \\
\hline S 8 & 0 & 0 & 0 & _ & _ \\
\hline S 9 & 3 & 1 & 4 & 75 & 25 \\
\hline S 10 & 2 & 1 & 3 & 66.67 & 33.33 \\
\hline S 11 & 4 & 0 & 4 & 100 & 0 \\
\hline S 12 & 4 & 3 & 7 & 57.14 & 42.86 \\
\hline$S 13$ & 10 & 7 & 17 & 58.82 & 41.18 \\
\hline S 14 & 1 & 0 & 1 & 100 & 0 \\
\hline S 15 & 19 & 13 & 32 & 59.38 & 40.63 \\
\hline S 16 & 32 & 2 & 34 & 94.12 & 5.88 \\
\hline S 17 & 32 & 0 & 32 & 100 & 0 \\
\hline S 18 & 40 & 0 & 40 & 100 & 0 \\
\hline S 19 & 17 & 0 & 17 & 100 & 0 \\
\hline S 20 & 38 & 0 & 38 & 100 & 0 \\
\hline S 21 & 34 & 2 & 36 & 94.44 & 5.56 \\
\hline S 22 & 28 & 0 & 28 & 100 & 0 \\
\hline Total & 266 & 29 & 295 & 90 & 10 \\
\hline
\end{tabular}

